\title{
Positron Emission Tomography Imaging of the Gastrin-Releasing Peptide Receptor with a Novel Bombesin Analogue
}

\author{
Joseph Lau, ${ }^{\dagger, \|}$ Etienne Rousseau, ${ }^{\dagger, \dagger, \|}$ Zhengxing Zhang, ${ }^{\dagger}$ Carlos F. Uribe, ${ }^{\dagger}$ Hsiou-Ting Kuo, ${ }^{\dagger}$ \\ Jutta Zeisler, ${ }^{\dagger}$ Chengcheng Zhang, ${ }^{\dagger}$ Daniel Kwon, ${ }^{\dagger}$ Kuo-Shyan Lin, ${ }^{*},, \S_{\odot}$ and François Bénard ${ }^{*}, \dagger, \S$
}

${ }^{\dagger}$ Department of Molecular Oncology, BC Cancer Research Centre, 675 West 10th Avenue, V5Z 1L3 Vancouver, British Columbia, Canada

${ }^{\ddagger}$ Département de Médecine Nucléaire et Radiobiologie, Université de Sherbrooke, $300112 \mathrm{e}$ Avenue Nord, J1H 5N4 Sherbrooke, Quebec, Canada

${ }^{\S}$ Department of Radiology, University of British Columbia, 2211 Wesbrook Mall, V6T 1Z7 Vancouver, British Columbia, Canada

Supporting Information

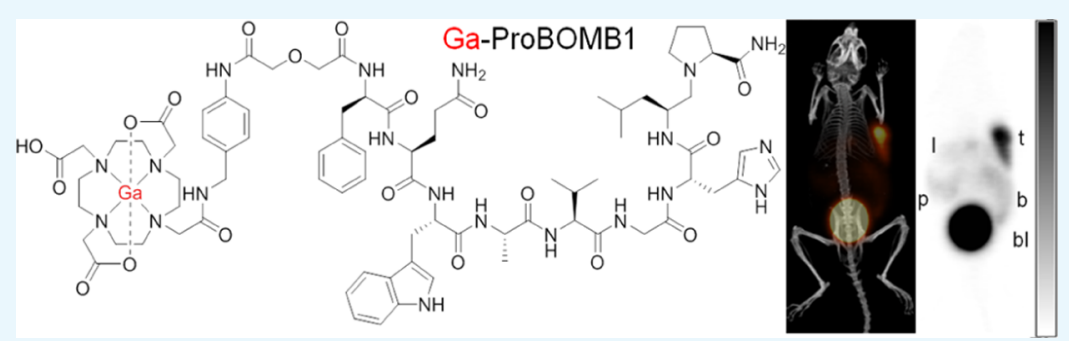

ABSTRACT: The gastrin-releasing peptide receptor (GRPR), a G protein-coupled receptor, is overexpressed in solid malignancies and particularly in prostate cancer. We synthesized a novel bombesin derivative, $\left[{ }^{68} \mathrm{Ga}\right] \mathrm{Ga}$-ProBOMB1, evaluated its pharmacokinetics and potential to image GRPR expression with positron emission tomography (PET), and compared it with $\left[{ }^{68} \mathrm{Ga}\right] \mathrm{Ga}-\mathrm{NeoBOMB} 1$. ProBOMB1 (DOTA-pABzA-DIG-D-Phe-Gln-Trp-Ala-Val-Gly-His-Leu- $\left.\psi\left(\mathrm{CH}_{2} \mathrm{~N}\right)-\mathrm{Pro}-\mathrm{NH}_{2}\right)$ was synthesized by solid-phase peptide synthesis. The polyaminocarboxylate chelator 1,4,7,10-tetraazacyclododecane-1,4,7,10-tetraacetic acid (DOTA) was coupled to the $N$-terminal and separated from the GRPR-targeting sequence by a $p$-aminomethylaniline-diglycolic acid (pABzA-DIG) linker. The binding affinity to GRPR was determined using a cell-based competition assay, whereas the agonist/antagonist property was determined with a calcium efflux assay. ProBOMB1 was radiolabeled with ${ }^{68} \mathrm{GaCl}_{3}$. PET imaging and biodistribution studies were performed in male immunocompromised mice bearing PC-3 prostate cancer xenografts. Blocking experiments were performed with coinjection of $\left[\mathrm{D}^{\mathrm{Phe}}{ }^{6}, \mathrm{Leu}^{-\mathrm{NHEt}}{ }^{13}\right.$, des$\mathrm{Met}^{14}$ ] bombesin(6-14). Dosimetry calculations were performed with OLINDA software. ProBOMB1 and the nonradioactive Ga-ProBOMB were obtained in 1.1 and $67 \%$ yield, respectively. The $K_{\mathrm{i}}$ value of Ga-ProBOMB1 for GRPR was $3.97 \pm 0.76 \mathrm{nM}$. Ga-ProBOMB1 behaved as an antagonist for GRPR. $\left[{ }^{68} \mathrm{Ga}\right] \mathrm{Ga}-\mathrm{ProBOMB} 1$ was obtained in $48.2 \pm 10.9 \%$ decay-corrected radiochemical yield with $121 \pm 46.9 \mathrm{GBq} /$ $\mu \mathrm{mol}$ molar activity and $>95 \%$ radiochemical purity. Imaging/biodistribution studies showed that the excretion of $\left[{ }^{68} \mathrm{Ga}\right] \mathrm{Ga}-\mathrm{ProBOMB} 1$ was primarily through the renal pathway. At $1 \mathrm{~h}$ postinjection (p.i.), PC-3 tumor xenografts were clearly delineated in PET images with excellent contrast. The tumor uptake for $\left[{ }^{68} \mathrm{Ga}\right] \mathrm{Ga}-\mathrm{ProBOMB} 1$ was $8.17 \pm 2.57$ percent injected dose per gram (\% ID/g) and $9.83 \pm 1.48 \% \mathrm{ID} / \mathrm{g}$ for $\left[{ }^{68} \mathrm{Ga}\right] \mathrm{Ga}-\mathrm{NeoBOMB} 1$, based on biodistribution studies at $1 \mathrm{~h}$ p.i. This corresponded to tumor-to-blood and tumor-to-muscle uptake ratios of $20.6 \pm 6.79$ and $106 \pm 57.7$ for $\left[{ }^{68} \mathrm{Ga}\right] \mathrm{Ga}-\mathrm{ProBOMB} 1$ and $8.38 \pm 0.78$ and $39.0 \pm 12.6$ for $\left[{ }^{68} \mathrm{Ga}\right]$ Ga-NeoBOMB1, respectively. Blockade with $\left[\mathrm{D}-\mathrm{Phe}{ }^{6}\right.$, Leu-NHEt ${ }^{13}$, des-Met $\left.{ }^{14}\right]$ bombesin(6-14) significantly reduced the average uptake of $\left[{ }^{68} \mathrm{Ga}\right]$ Ga-ProBOMB1 in tumors by $62 \%$. The total absorbed dose was lower for $\left[{ }^{68} \mathrm{Ga}\right] \mathrm{Ga}$-ProBOMB1 in all organs except for bladder compared with $\left[{ }^{68} \mathrm{Ga}\right] \mathrm{Ga}-\mathrm{NeoBOMB} 1$. Our data suggest that $\left[{ }^{68} \mathrm{Ga}\right] \mathrm{Ga}-\mathrm{ProBOMB} 1$ is an excellent radiotracer for imaging GRPR expression with PET. $\left[{ }^{68} \mathrm{Ga}\right] \mathrm{Ga}-\mathrm{ProBOMB} 1$ achieved a similar uptake as $\left[{ }^{68} \mathrm{Ga}\right] \mathrm{Ga}-\mathrm{NeoBOMB} 1$ in tumors, with enhanced contrast and lower whole-body absorbed dose.

\section{INTRODUCTION}

Gastrin-releasing peptide receptor (GRPR) is a G proteincoupled receptor of the bombesin $(\mathrm{BBN})$ receptor family. ${ }^{1-3}$ Together with its endogenous ligand, gastrin-releasing peptide, GRPR is involved in synaptic plasticity, emotional, and feeding behavior, hormone secretion, smooth muscle contraction, and cell proliferation. ${ }^{1-3}$ In normal conditions, the expression of GRPR is restricted to the central nervous system, pancreas, adrenal cortex, and gastrointestinal tract. ${ }^{4}$ GRPR is also implicated in neoplastic progression, with overexpression of GRPR having been reported in many cancer subtypes including lung, head and neck, colon, kidney, ovarian, breast, and prostate cancers. ${ }^{5}$ This ectopic expression in cancers makes it an attractive target for personalized therapies.

Received: November 26, 2018

Accepted: January 3, 2019

Published: January 16, 2019 


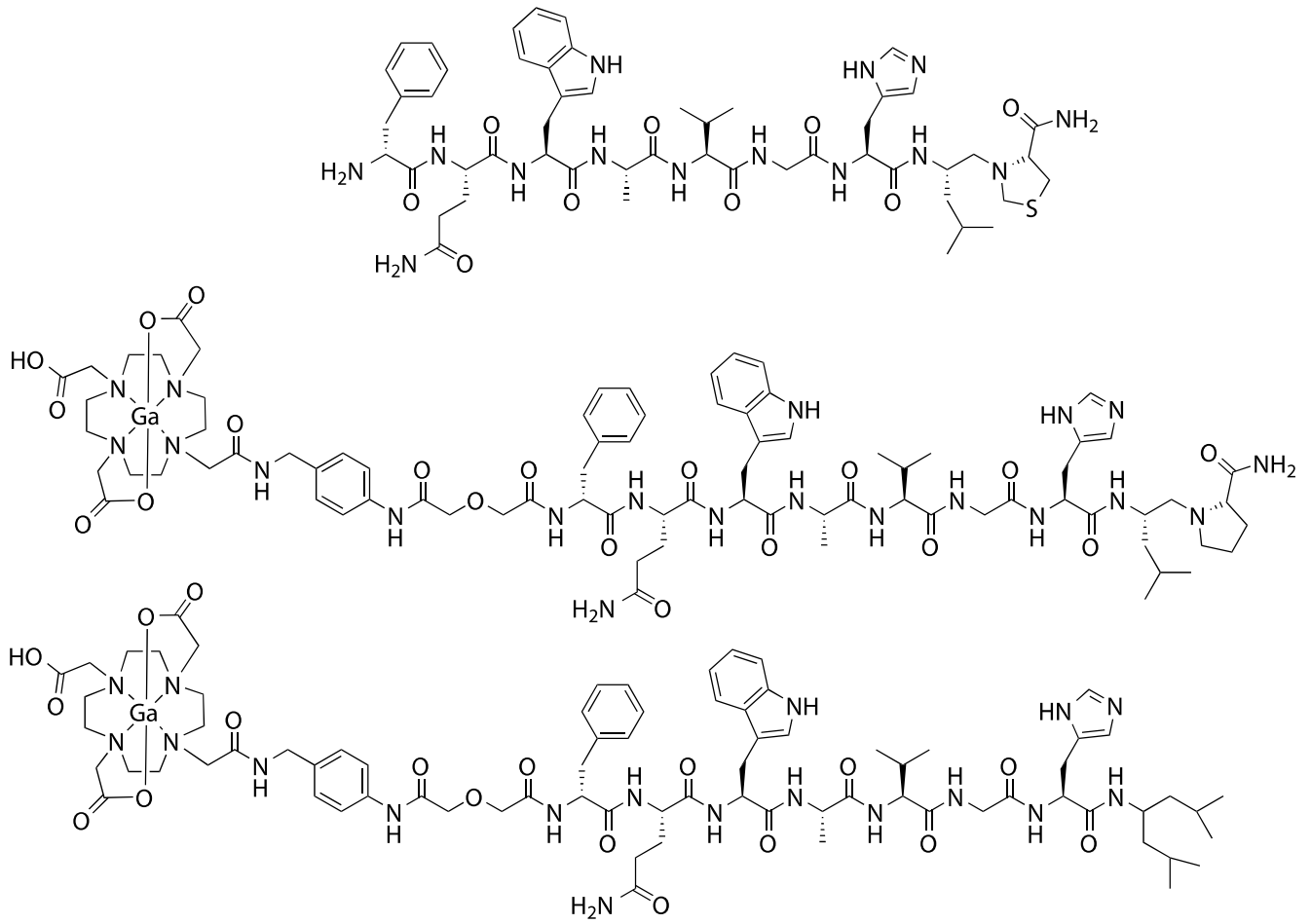

Figure 1. Chemical structures of RC-3950-II (top), Ga-ProBOMB1 (middle), and Ga-NeoBOMB1 (bottom).

BBN (Pyr-Gln-Arg-Leu-Gly-Asn-Gln-Trp-Ala-Val-Gly-HisLeu-Met- $\mathrm{NH}_{2}$ ) derivatives have been radiolabeled for imaging with single photon emission computed tomography (SPECT) and positron emission tomography (PET) and for therapy with beta and alpha emitters. ${ }^{6-8}$ The minimum sequence required for GRPR binding is BBN(7-14). ${ }^{9}$ Often, the radiolabel complex is appended directly onto the structure or via a linker at the $\mathrm{N}$ terminus, while modifications at the $\mathrm{C}$-terminus dictates agonist/antagonist properties. For targeting GRPR, antagonists are preferred because agonists have been shown to induce gastrointestinal adverse events. ${ }^{10}$ Examples of GRPR antagonists evaluated in the clinic include $\left[{ }^{68} \mathrm{Ga}\right] \mathrm{Ga}-\mathrm{RM} 2,\left[{ }^{68} \mathrm{Ga}\right] \mathrm{Ga}-$ SB3, $\left[{ }^{68} \mathrm{Ga}\right]$ Ga-NeoBOMB1, $\left[{ }^{68} \mathrm{Ga}\right]$ Ga-RM26, $\left[{ }^{18} \mathrm{~F}\right] \mathrm{F}-\mathrm{BAY}-$ 864367, and $\left[{ }^{64} \mathrm{Cu}\right] \mathrm{Cu}-\mathrm{CB}-\mathrm{TE} 2 \mathrm{~A}-\mathrm{AR} 06 .{ }^{9,11-16}$

Coy et al. reported that reduction of the peptide bond between residues 13 and 14 of $\mathrm{BBN}$ to $-\mathrm{CH}_{2}-\mathrm{NH}-$ can yield potent antagonists. ${ }^{17}$ On the basis of this work, the Schally group reported a series of pseudononapetide BBN antagonists with a reduced bond $\left(\mathrm{CH}_{2}-\mathrm{NH}\right.$ or $\left.\mathrm{CH}_{2}-\mathrm{N}\right)$ between residues 13-14 $\left(\mathrm{Leu}^{13} \psi \mathrm{AA}^{14}\right){ }^{18}$ Several of those exhibited picomolar binding affinity for murine GRPR and some were able to inhibit growth of prostate, breast, colon, lung, liver, pancreas, ovary, kidney, and glioma cancers in preclinical models. ${ }^{5,19-23}$ Despite their high binding affinity and antitumor activity, to the best of our knowledge, no radiolabeled $\left[\mathrm{Leu}^{13} \psi \mathrm{AA}^{14}\right] \mathrm{BBN}$ derivative has been reported for cancer imaging. We report the synthesis and biological evaluation of a novel BBN antagonist, $\left[{ }^{68} \mathrm{Ga}\right] \mathrm{Ga}$ ProBOMB1 $\quad\left({ }^{68} \mathrm{Ga}-\mathrm{DOTA}\right.$-pABzA-DIG-D-Phe-Gln-Trp-AlaVal-Gly-His-Leu- $\psi$-Pro- $\mathrm{NH}_{2}$ ), based on the sequence of the previously reported RC-3950-II (D-Phe-Gln-Trp-Ala-Val-GlyHis-Leu- $\psi$-Tac- $\mathrm{NH}_{2}$; Tac: 4-thiazolidinecarboxylic acid; Figure 1).

\section{RESULTS}

Chemistry, Radiolabeling, and Hydrophilicity. The radiolabeling precursors ProBOMB1 and NeoBOMB1 were obtained in 1.1 and $39 \%$ yields, respectively. The nonradioactive standards Ga-ProBOMB1 and Ga-NeoBOMB1 were obtained in 67 and $38 \%$ yields, respectively. $\left[{ }^{68} \mathrm{Ga}\right] \mathrm{Ga}-\mathrm{ProBOMB} 1$ was obtained in $48.2 \pm 10.9 \%$ decayed-corrected isolated yield with $121 \pm 46.9 \mathrm{GBq} / \mu \mathrm{mol}$ molar activity and $96.9 \pm 1.4 \%$ radiochemical purity $(n=6)$. $\left[{ }^{68} \mathrm{Ga}\right] \mathrm{Ga}-\mathrm{NeoBOMB} 1$ was obtained in $34.0 \pm 11.8 \%$ decayed-corrected isolated yield with $239 \pm 87.3 \mathrm{GBq} / \mu \mathrm{mol}$ molar activity and $96.4 \pm 0.8 \%$ radiochemical purity $(n=3) \cdot \log D_{74}$ values of $\left[{ }^{68} \mathrm{Ga}\right] \mathrm{Ga}$ ProBOMB1 and $\left[{ }^{68} \mathrm{Ga}\right] \mathrm{Ga}-\mathrm{NeoBOMB} 1$ were $-2.34 \pm 0.05$ and $-0.88 \pm 0.02(n=3)$, respectively.

Binding Affinity and Agonist/Antagonist Characterization. The binding affinities of $\left[\mathrm{D}-\mathrm{Phe}^{6}, \mathrm{Leu}-\mathrm{NHEt}^{13}{ }^{3}\right.$,des$\mathrm{Met}^{14}$ bombesin(6-14), Ga-ProBOMB1, and Ga-NeoBOMB1 for GRPR were measured in PC-3 cells (Supporting Information Figure S1). The compounds successfully displaced binding of $\left.{ }^{125} \mathrm{I}^{-\mathrm{Tyr}^{4}}\right]$ bombesin in a dose-dependent manner. $K_{\mathrm{i}}$ values for $\left[\mathrm{D}-\mathrm{Phe}^{6}\right.$, Leu-NHEt ${ }^{13}$, des-Met ${ }^{14}$ bombesin(6-14), Ga-ProBOMB1, and Ga-NeoBOMB1 were $10.7 \pm 1.06,3.97 \pm 0.76$, and $1.71 \pm 0.28 \mathrm{nM}$, respectively. Differences in binding affinity were statistically significant between compounds $(p<0.05)$.

Intracellular calcium release of PC-3 cells was measured for Ga-ProBOMB1 (Figure 2 and Supporting Information Figure S2). Bombesin (5 and $50 \mathrm{nM}$ ) and adenosine triphosphate (ATP) $(50 \mathrm{nM})$ induced calcium release corresponding to 535 $\pm 52.0,549 \pm 58.7,511 \pm 45.5$ RFUs, compared with $18.3 \pm 5.4$ RFUs for buffer control. Differences were statistically significant $(p<0.001)$. For $\left[\mathrm{D}-\mathrm{Phe}^{6}, \mathrm{Leu}_{\mathrm{NHEt}}{ }^{13}\right.$, des-Met $\left.{ }^{14}\right]$ bombesin $(6-$ 14) $(5$ and $50 \mathrm{nM}), 22.3 \pm 16.8$ and $42.0 \pm 20.4$ RFUs were observed, while $22.3 \pm 14.4$ and $16.0 \pm 3.7$ RFUs were observed for Ga-ProBOMB1 (5 and $50 \mathrm{nM}$ ). Differences compared with buffer control were not statistically significant. 


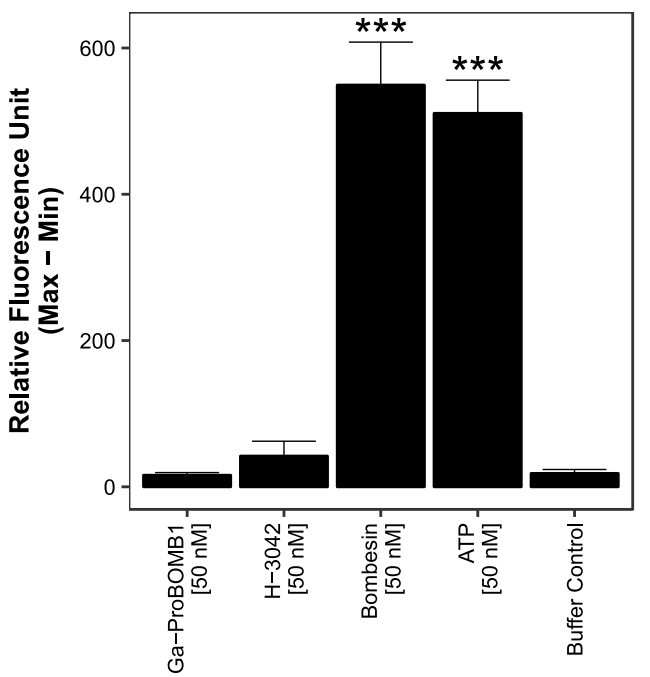

Figure 2. Intracellular calcium efflux in PC-3 cells. Cells were incubated with $50 \mathrm{nM}$ of Ga-ProBOMB1, H-3042 ([D-Phe ${ }^{6}$,Leu-NHEt ${ }^{13}$, des$\left.\mathrm{Met}^{14}\right]$ bombesin(6-14)), bombesin, ATP, or buffer control. ***p $\leq$ 0.001 compared with buffer control.

PET Imaging, Biodistribution, and Stability. Representative maximum intensity projection PET/CT images ( 1 and $2 \mathrm{~h}$ p.i.) are shown in Figure 3. $\left[{ }^{68} \mathrm{Ga}\right] \mathrm{Ga}-P r o B O M B 1$ and $\left[{ }^{68} \mathrm{Ga}\right] \mathrm{Ga}-\mathrm{NeoBOMB} 1$ enabled clear visualization of PC-3 tumor xenografts. $\left[{ }^{68} \mathrm{Ga}\right] \mathrm{Ga}-\mathrm{NeoBOMB} 1$ was excreted via both the hepatobiliary and renal pathways, while $\left[{ }^{68} \mathrm{Ga}\right] \mathrm{Ga}$ ProBOMB1 was primarily cleared through the renal pathway. For $\left[{ }^{68} \mathrm{Ga}\right] \mathrm{Ga}-\mathrm{ProBOMB} 1$, the highest activity was observed in bladder followed by tumor. For $\left[{ }^{68} \mathrm{Ga}\right] \mathrm{Ga}-\mathrm{NeoBOMB} 1$, activity was observed in tumor, liver, pancreas, bowel, and bladder. Faster clearance of $\left[{ }^{68} \mathrm{Ga}\right] \mathrm{Ga}$-ProBOMB1 compared with $\left[{ }^{68} \mathrm{Ga}\right] \mathrm{Ga}-\mathrm{NeoBOMB1}$ led to higher contrast images. Coinjection of $\left[\mathrm{D}-\mathrm{Phe}^{6}{ }^{6}\right.$ Leu-NHEt ${ }^{13}{ }^{3}$, des-Met $\left.{ }^{14}\right]$ bombesin (6-14) decreased the average uptake of $\left[{ }^{68} \mathrm{Ga}\right] \mathrm{Ga}-\mathrm{ProBOMB} 1$ in tumors by $62 \%$.

For biodistribution, uptake (\% ID/g) of selected organs for $\left[{ }^{68} \mathrm{Ga}\right] \mathrm{Ga}-\mathrm{NeoBOMB} 1$ and $\left[{ }^{68} \mathrm{Ga}\right] \mathrm{Ga}$-ProBOMB1 were compared (Figure 4). Thirty minutes p.i., the PC-3 tumor uptake was lower for $\left[{ }^{68} \mathrm{Ga}\right] \mathrm{Ga}-\mathrm{ProBOMB} 1(4.62 \pm 2.13)$ than for $\left[{ }^{68} \mathrm{Ga}\right]$ Ga-NeoBOMB1 $(9.60 \pm 0.99)(p<0.001)$. The tumor uptake of $\left[{ }^{68} \mathrm{Ga}\right] \mathrm{Ga}-\mathrm{ProBOMB} 1$ was $8.17 \pm 2.13$ at $60 \mathrm{~min}$ and $8.31 \pm 3.88$ at $120 \mathrm{~min}$ and that of $\left[{ }^{68} \mathrm{Ga}\right] \mathrm{Ga}-\mathrm{NeoBOMB} 1$ was $9.83 \pm 1.48$ at $60 \mathrm{~min}$ and $12.1 \pm 3.72$ at $120 \mathrm{~min}$ (not significantly different). Uptake of blood, liver, pancreas, and kidney for $\left[{ }^{68} \mathrm{Ga}\right] \mathrm{Ga}-P r o B O M B 1$ was lower than that for $\left[{ }^{68} \mathrm{Ga}\right] \mathrm{Ga}-\mathrm{NeoBOMB} 1$ at all time-points $(p<0.05)$. In particular, pancreatic uptake was markedly lower at 30,60 , and $120 \mathrm{~min}$ for $\left[{ }^{68} \mathrm{Ga}\right] \mathrm{Ga}$-ProBOMB1 (respectively: $10.4 \pm$ $3.79,4.68 \pm 1.26,1.55 \pm 0.49)$ compared with $\left[{ }^{68} \mathrm{Ga}\right] \mathrm{Ga}-$ NeoBOMB1 (respectively: $95.7 \pm 12.7,122 \pm 28.4,139 \pm$ 26.8). Muscle uptake was only significantly lower in $\left[{ }^{68} \mathrm{Ga}\right] \mathrm{Ga}$ ProBOMB1 versus $\left[{ }^{68} \mathrm{Ga}\right] \mathrm{Ga}-\mathrm{NeoBOMB} 1$ at 60 and $120 \mathrm{~min}(p$ $<0.01$ ). For all other collected organs (Supporting Information Tables S1 and S2), with the exception of seminal vesicles at 60 $\mathrm{min}$, there was less uptake with $\left[{ }^{68} \mathrm{Ga}\right] \mathrm{Ga}$-ProBOMB1 than $\left[{ }^{68} \mathrm{Ga}\right] \mathrm{Ga}-\mathrm{NeoBOMB} 1$, although that was not always statistically significant. When co-injected with $\left[\mathrm{D}-\mathrm{Phe}^{6}\right.$,Leu$\mathrm{NHEt}^{13}$, des-Met $\left.{ }^{14}\right]$ bombesin(6-14) (Figure 5), tumor uptake of $\left[{ }^{68} \mathrm{Ga}\right] \mathrm{Ga}-\mathrm{ProBOMB} 1$ at $60 \mathrm{~min}$ was significantly reduced to $3.12 \pm 1.68(p<0.01)$. Injected radiolabeled peptide mass for $\left[{ }^{68} \mathrm{Ga}\right] \mathrm{Ga}-\mathrm{NeoBOMB} 1(6.01 \pm 2.89 \mathrm{pmol})$ and $\left[{ }^{68} \mathrm{Ga}\right] \mathrm{Ga}-$ ProBOMB1 $(20.24 \pm 12.9 \mathrm{pmol})$ was different $(p<0.001)$ but had overlapping ranges at 30 and $60 \mathrm{~min}$.

The stability of $\left[{ }^{68} \mathrm{Ga}\right] \mathrm{Ga}-\mathrm{ProBOMB} 1$ was measured in plasma at $5 \mathrm{~min}$ postinjection (p.i.). According to highperformance liquid chromatography (HPLC) results (Figure 6), $\left[{ }^{68} \mathrm{Ga}\right] \mathrm{Ga}-\mathrm{ProBOMB} 1\left(t_{\mathrm{R}}=8.84 \mathrm{~min}\right)$ was $96.3 \pm 2.7 \%$ intact. A minor metabolite peak was observed at $t_{\mathrm{R}}=2.72 \mathrm{~min}$.

Dosimetry. The absorbed doses in mice are shown in Figure 7 and Supporting Information Table S3, based on kinetic curves derived from biodistribution data (Supporting Information Figures S3 and S4). The organ that received the highest dose from $\left[{ }^{68} \mathrm{Ga}\right] \mathrm{Ga}$-ProBOMB1 was the urinary bladder (10.00 $\mathrm{mGy} / \mathrm{MBq}$ ). Besides the urinary bladder, all other organs received less than $1 \mathrm{mGy} / \mathrm{MBq}$. Higher doses were observed for $\left[{ }^{68} \mathrm{Ga}\right] \mathrm{Ga}-\mathrm{NeoBOMB} 1$ in most organs including pancreas $(8.00$ $\mathrm{mGy} / \mathrm{MBq})$, kidneys (3.29 $\mathrm{mGy} / \mathrm{MBq})$, and large and small intestines (3.24 and $3.15 \mathrm{mGy} / \mathrm{MBq})$.

The estimated absorbed whole-body dose for an average adult human male was also computed (Table 1). Consistent with the mouse model, higher doses were obtained for $\left[{ }^{68} \mathrm{Ga}\right] \mathrm{Ga}$ NeoBOMB1 than $\left[{ }^{68} \mathrm{Ga}\right] \mathrm{Ga}-P r o B O M B 1$ across all organs except for bladder $\left(5.69 \times 10^{-2}\right.$ vs $\left.6.59 \times 10^{-2} \mathrm{mGy} / \mathrm{MBq}\right)$. Notably, the pancreas is expected to receive $2.63 \times 10^{-1} \mathrm{mGy} /$ $\mathrm{MBq}$ for $\left[{ }^{68} \mathrm{Ga}\right] \mathrm{Ga}-\mathrm{NeoBOMB} 1$ versus $1.44 \times 10^{-2} \mathrm{mGy} / \mathrm{MBq}$ for $\left[{ }^{68} \mathrm{Ga}\right] \mathrm{Ga}$-ProBOMB1. The kidney is expected to receive $1.69 \times 10^{-2} \mathrm{mGy} / \mathrm{MBq}$ for $\left[{ }^{68} \mathrm{Ga}\right] \mathrm{Ga}-\mathrm{NeoBOMB} 1$ versus 4.32 $\times 10^{-3} \mathrm{mGy} / \mathrm{MBq}$ for $\left[{ }^{68} \mathrm{Ga}\right] \mathrm{Ga}-\mathrm{ProBOMB} 1$.

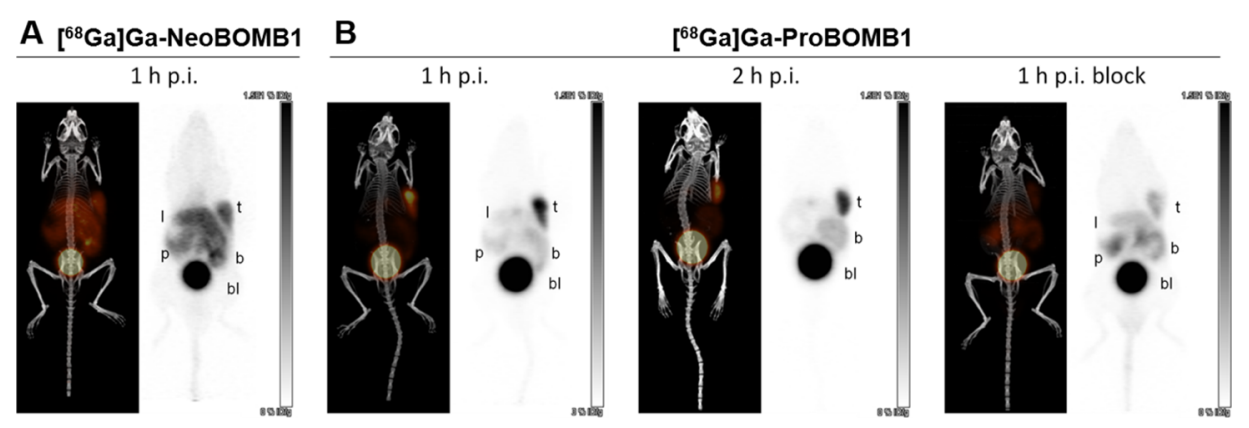

Figure 3. Maximum intensity projections for PET/CT and PET alone with (A) $\left[{ }^{68} \mathrm{Ga}\right] \mathrm{Ga}-\mathrm{NeoBOMB} 1$ and $(\mathrm{B})\left[{ }^{68} \mathrm{Ga}\right] \mathrm{Ga}-\mathrm{ProBOMB} 1$ acquired at 1 or $2 \mathrm{~h}$ p.i. in mice bearing PC-3 tumor xenografts. Blocking was performed with coinjection of $100 \mu \mathrm{g}$ of [D-Phe ${ }^{6}$, Leu-NHEt $^{13}$, des-Met $\left.{ }^{14}\right]$ bombesin $(6-$ 14). Color bar is in units of $\% \mathrm{ID} / \mathrm{g}$ from 0 to $15 . \mathrm{t}=$ tumor; $\mathrm{l}=$ liver; $\mathrm{p}=$ pancreas; $\mathrm{b}=$ bowel; $\mathrm{bl}=$ bladder. 

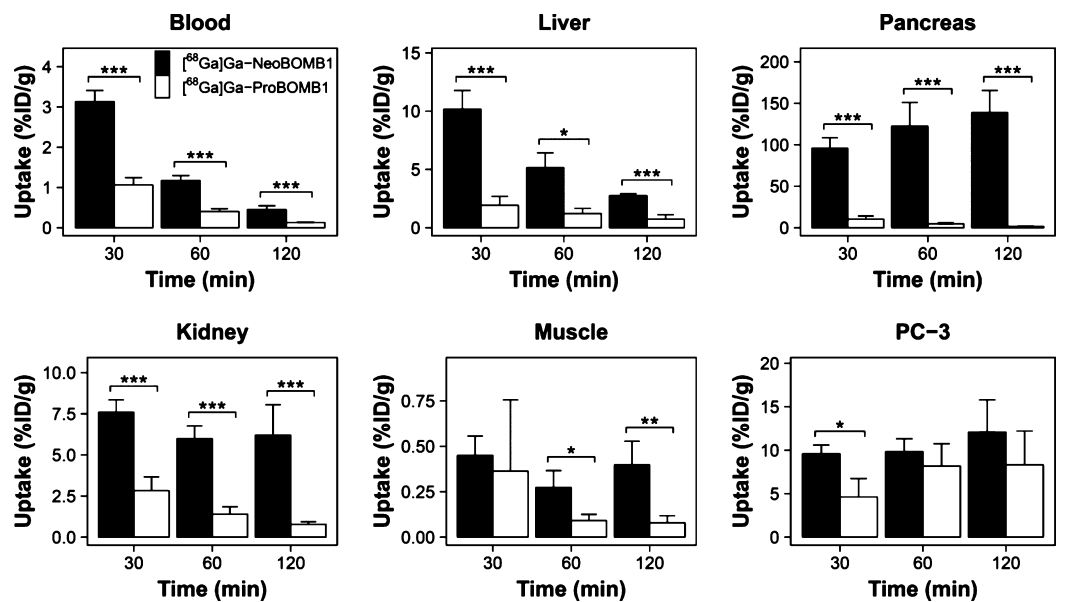

Figure 4. Biodistribution of $\left[{ }^{68} \mathrm{Ga}\right] \mathrm{Ga}-\mathrm{NeoBOMB} 1$ and $\left[{ }^{68} \mathrm{Ga}\right] \mathrm{Ga}$-ProBOMB1 in selected tissues at multiple time points. ${ }^{*} p \leq 0.05 ; * * p \leq 0.01 ; * * *$ $\leq 0.001$.

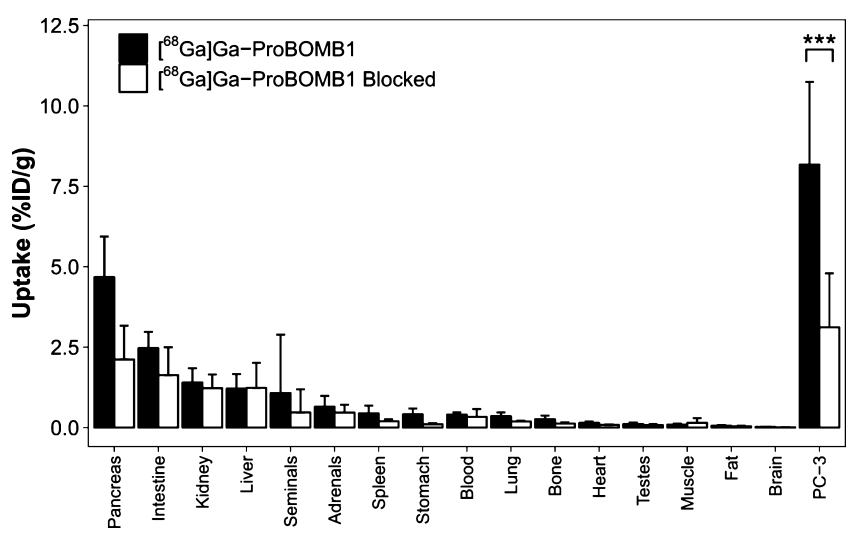

Figure 5. Biodistribution of $\left[{ }^{68} \mathrm{Ga}\right] \mathrm{Ga}-\mathrm{ProBOMB} 1$ at $60 \mathrm{~min}$ p.i. with or without coinjection of $100 \mu \mathrm{g}$ of $\left[\mathrm{D}-\mathrm{Phe}^{6}\right.$, Leu-NHEt $^{13}$, des-Met $\left.{ }^{14}\right]$ bombesin(6-14). ***p $\leq 0.001$.

\section{DISCUSSION}

There is longstanding interest in the development of radiopharmaceuticals targeting GRPR, because of overexpression of this receptor in cancer. The overexpression is strongly correlated with estrogen receptor positivity in breast cancer, ${ }^{24}$ and cohort studies have shown GRPR antagonists to be effective in detecting primary and metastatic lesions in patients. ${ }^{12,25}$ There is extensive literature supporting the use of GRPR radiopharmaceuticals for prostate cancer in patients. ${ }^{6,9,26}$ Because of tumor heterogeneity, it has been postulated that GRPR radiotheranostics can complement prostate-specific membrane antigen agents to improve prostate cancer management. $^{27,28}$

We synthesized $\left[{ }^{68} \mathrm{Ga}\right] \mathrm{Ga}$-ProBOMB1 based on the sequence of RC-3950-II, a [Leu $\left.{ }^{13} \psi \mathrm{AA}^{14}\right] \mathrm{BBN}$ derivative. ${ }^{17}$ We replaced the last amino acid $\mathrm{Tac}^{14}$ with $\mathrm{Pro}^{14}$, as proline shows good structural homology (Figure 1) and is readily available from commercial sources. Following the conjugation of $\mathrm{Pro}^{14}$ to the rink-amide resin, we conducted reductive amination on solidphase to form Fmoc-Leu- $\psi\left(\mathrm{CH}_{2} \mathrm{~N}\right)$-Pro-resin. The low isolated yield of ProBOMB1 is likely because of the low yield of this reductive amination step. While sufficient precursor was obtained for preclinical studies, further optimization will be required for clinical translation. For example, it may be better to first couple Leu to Pro via reductive amination in solution phase

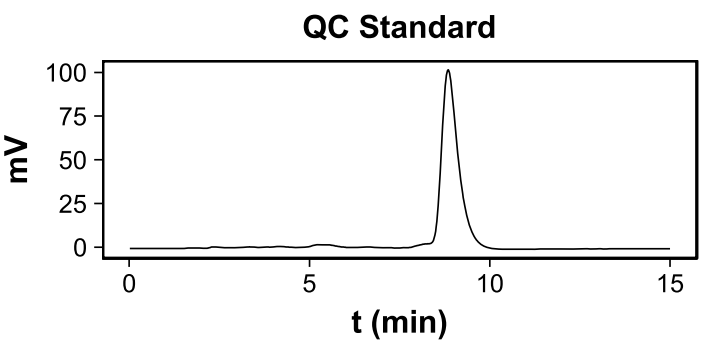

Blood 5 min post-injection - Mouse 1

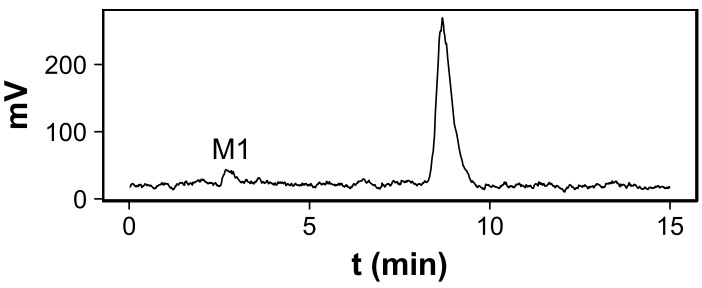

Blood 5 min post-injection - Mouse 2

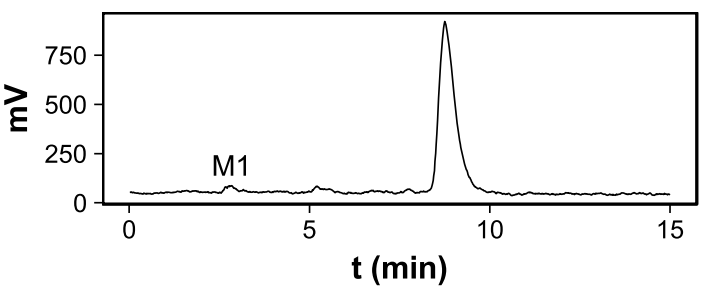

Figure 6. Plasma stability of $\left[{ }^{68} \mathrm{Ga}\right] \mathrm{Ga}-\mathrm{ProBOMB} 1$ at $5 \mathrm{~min}$ p.i. Minor metabolite peak M1 was observed at $t_{\mathrm{R}}=2.72 \mathrm{~min}$ on HPLC chromatograms.

before coupling onto the resin. Compared with the native BBN sequence, RC-3950-II also has a D-Phe ${ }^{6}$ substitution which enhances binding potency ${ }^{29}$ and is present in other antagonists such as RM2 ${ }^{15}$ and NeoBOMB1. ${ }^{13,30}$ The radiometal/chelator complex ( $\left[{ }^{68} \mathrm{Ga}\right] \mathrm{Ga}$-DOTA $)$ was appended at the N-terminus of the GRPR-targeting sequence and separated by a pABzA-DIG linker, a modular design that parallels that of $\left[{ }^{68} \mathrm{Ga}\right] \mathrm{Ga}-$ NeoBOMB1. Recently, Nock et al. presented the first-in man study in four prostate cancer patients. ${ }^{13}\left[{ }^{68} \mathrm{Ga}\right] \mathrm{Ga}-\mathrm{NeoBOMB} 1$ was well-tolerated and generated high-contrast PET images. The tracer successfully localized to the primary prostate tumor and distant metastatic sites (lymph nodes, liver, and bone). The 


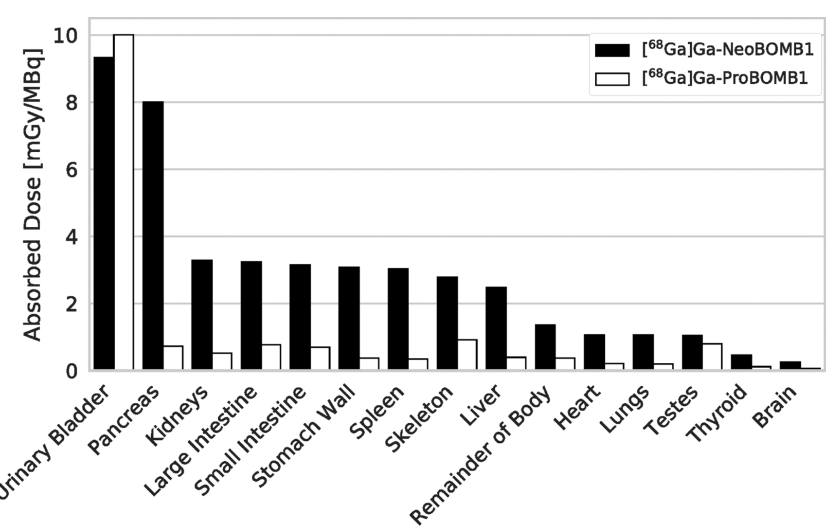

Figure 7. Absorbed doses per unit of injected activity in mice for $\left[{ }^{68} \mathrm{Ga}\right] \mathrm{Ga}-\mathrm{NeoBOMB} 1$ and $\left[{ }^{68} \mathrm{Ga}\right] \mathrm{Ga}$-ProBOMB1.

Table 1. Estimated Absorbed Doses for Different Organs in the Adult Human Male Calculated with OLINDA Software

\begin{tabular}{|c|c|c|}
\hline target organ & $\begin{array}{c}{\left[{ }^{68} \mathrm{Ga}\right] \mathrm{Ga}-\mathrm{NeoBOMB} 1} \\
\text { absorbed dose }[\mathrm{mGy} / \mathrm{MBq}]\end{array}$ & $\begin{array}{c}{\left[{ }^{68} \mathrm{Ga}\right] \mathrm{Ga}-\mathrm{ProBOMB} 1} \\
\text { absorbed dose }[\mathrm{mGy} / \mathrm{MBq}]\end{array}$ \\
\hline adrenals & 0.041600 & 0.002400 \\
\hline brain & 0.000316 & 0.000088 \\
\hline esophagus & 0.002710 & 0.000450 \\
\hline eyes & 0.000622 & 0.000193 \\
\hline $\begin{array}{l}\text { gallbladder } \\
\text { wall }\end{array}$ & 0.004800 & 0.000959 \\
\hline left colon & 0.032100 & 0.006150 \\
\hline $\begin{array}{l}\text { small } \\
\text { intestine }\end{array}$ & 0.029300 & 0.005990 \\
\hline stomach wall & 0.009990 & 0.001030 \\
\hline right colon & 0.016700 & 0.003440 \\
\hline rectum & 0.015000 & 0.004080 \\
\hline heart & 0.006160 & 0.001520 \\
\hline hidneys & 0.016900 & 0.004320 \\
\hline liver & 0.018800 & 0.003650 \\
\hline lungs & 0.013800 & 0.001090 \\
\hline pancreas & 0.263000 & 0.014400 \\
\hline prostate & 0.002830 & 0.002100 \\
\hline $\begin{array}{l}\text { salivary } \\
\text { glands }\end{array}$ & 0.000722 & 0.000214 \\
\hline red marrow & 0.002140 & 0.000685 \\
\hline skeleton & 0.001440 & 0.000452 \\
\hline spleen & 0.009440 & 0.001260 \\
\hline testes & 0.001310 & 0.000880 \\
\hline thymus & 0.001720 & 0.000356 \\
\hline thyroid & 0.001220 & 0.000264 \\
\hline $\begin{array}{l}\text { urinary } \\
\text { bladder } \\
\text { wall }\end{array}$ & 0.056900 & 0.065900 \\
\hline $\begin{array}{l}\text { remainder of } \\
\text { body }\end{array}$ & 0.003050 & 0.000962 \\
\hline
\end{tabular}

authors are exploring the use of ${ }^{177} \mathrm{Lu}$-labeled NeoBOMB1 for peptide receptor radionuclide therapy.

The $K_{\mathrm{i}}$ value of Ga-ProBOMB1 for GRPR $(3.97 \pm 0.76 \mathrm{nM})$ was approximately twofold higher than Ga-NeoBOMB1. It was also higher than the reported value for RC-3950-II $(0.078 \mathrm{nM})$; however, the latter value was determined using murine Swiss $3 \mathrm{~T} 3$ cells. ${ }^{17}$ We proceeded to study the agonist/antagonist properties of Ga-ProBOMB1 using a calcium efflux assay (Figure 2). While BBN and ATP significantly induced intracellular calcium release ( $>500 \mathrm{RFUs}$ ) compared with buffer control (18.3 \pm 5.4 RFUs), Ga-ProBOMB1 behaved as an antagonist and did not significantly induce calcium release ( 16.0 \pm 3.7 RFUs). For GRPR, this property is important for tolerability in humans. Moreover, for selected peptide-receptor systems such as somatostatin, there is a paradigm shift, favoring the use of antagonists over agonists for tumor targeting. ${ }^{31}$

PET imaging demonstrated that $\left[{ }^{68} \mathrm{Ga}\right] \mathrm{Ga}-\mathrm{ProBOMB} 1$ and $\left[{ }^{68} \mathrm{Ga}\right] \mathrm{Ga}-\mathrm{NeoBOMB} 1$ were able to detect GRPR-expressing PC-3 prostate cancer xenografts (Figure 3 ). $\left.{ }^{68} \mathrm{Ga}\right] \mathrm{Ga}$ ProBOMB1 cleared rapidly through the renal pathway to yield high-contrast images at $1 \mathrm{~h}$ p.i. We noted that tumor uptake was retained at $2 \mathrm{~h}$ p.i. for $\left[{ }^{68} \mathrm{Ga}\right] \mathrm{Ga}-\mathrm{ProBOMB} 1$, in conjunction with a further reduction in background activity. This suggests the optimal imaging window can be extended beyond $1 \mathrm{~h}$ timepoint without compromising sensitivity or contrast. Target specificity was confirmed with successful tumor blockade with $\left[\mathrm{D}-\mathrm{Phe}^{6}\right.$, Leu-NHEt ${ }^{13}$, des-Met $\left.{ }^{14}\right]$ bombesin(6-14).

Our biodistribution data were in agreement with PET imaging studies (Figures 4 and 5). The uptake of $\left[{ }^{68} \mathrm{Ga}\right] \mathrm{Ga}$-ProBOMB1 $(\% \mathrm{ID} / \mathrm{g})$ in tumor increased from $4.62 \pm 2.13$ at $30 \mathrm{~min}$ to 8.31 \pm 3.88 at $2 \mathrm{~h}$. Similarly, the uptake of $\left[{ }^{68} \mathrm{Ga}\right] \mathrm{Ga}-\mathrm{NeoBOMB} 1$ in tumor increased from $9.60 \pm 0.99$ at $30 \mathrm{~min}$ to $12.1 \pm 3.72$ at $2 \mathrm{~h}$. $\left[{ }^{68} \mathrm{Ga}\right]$ Ga-ProBOMB1 showed slower tumor targeting and accumulation but faster clearance from blood $(0.13 \pm 0.01 \mathrm{vs}$ $0.45 \pm 0.10$ at $2 \mathrm{~h}$ ) than $\left.\left[{ }^{68} \mathrm{Ga}\right] \mathrm{Ga}-\mathrm{NeoBOMB} 1 .{ }^{68} \mathrm{Ga}\right] \mathrm{Ga}-$ ProBOMB1 had better contrast ratios at $1 \mathrm{~h}$ p.i.: tumor-to-blood $(20.6 \pm 6.79$ vs $8.38 \pm 0.78)$, tumor-to-muscle $(106 \pm 57.7$ vs $39.0 \pm 12.6)$, tumor-to-kidney $(6.25 \pm 2.33$ vs $1.66 \pm 0.26)$, and tumor-to-liver $(7.33 \pm 2.97$ vs $2.00 \pm 0.55)$. The slightly lower uptake of $\left[{ }^{68} \mathrm{Ga}\right] \mathrm{Ga}$-ProBOMB1 in tumor xenografts can be explained by its lower binding affinity to GRPR, whereas the better contrast can be attributed to differences in hydrophilicity. Interestingly, we observed significantly lower pancreas uptake for $\left[{ }^{68} \mathrm{Ga}\right] \mathrm{Ga}$-ProBOMB1 $(4.68 \pm 1.26$ and $1.55 \pm 0.49 \% \mathrm{ID} / \mathrm{g}$ at 1 and $2 \mathrm{~h})$ compared with $\left[{ }^{68} \mathrm{Ga}\right] \mathrm{Ga}$-NeoBOMB1 $(123 \pm 28.4$ and $139 \pm 26.8 \% \mathrm{ID} / \mathrm{g}$ at 1 and $2 \mathrm{~h}$ ). The results obtained for $\left[{ }^{68} \mathrm{Ga}\right] \mathrm{Ga}-\mathrm{NeoBOMB} 1$ were comparable to those presented by Dalm et al., ${ }^{30}$ with the exception of the higher pancreas uptake noted in our study. The high pancreas uptake of $\left[{ }^{68} \mathrm{Ga}\right] \mathrm{Ga}$ NeoBOMB 1 can potentially be attributed to differences in molar activity and/or mouse strain. Dalm et al. injected $250 \mathrm{pmol}$ of $\left[{ }^{68} \mathrm{Ga}\right] \mathrm{Ga}-\mathrm{NeoBOMB} 1$ for biodistribution studies, and uptake in tumor and pancreas was approximately $\sim 10$ and $15 \% \mathrm{ID} / \mathrm{g}$, respectively, in nude mice bearing PC-3 tumors. ${ }^{30}$ From the same paper, when greater mass of peptide was injected for $\left[{ }^{177} \mathrm{Lu}\right] \mathrm{Lu}-\mathrm{NeoBOMB} 1$ (200 vs $10 \mathrm{pmol}$ ), pancreas uptake was reduced.

A general limitation of BBN-based radiopharmaceuticals is their metabolic stability, as BBN is susceptible to enzymatic cleavage by neutral endopeptidase. ${ }^{32,33}\left[{ }^{68} \mathrm{Ga}\right] \mathrm{Ga}$-ProBOMB1 was $>95 \%$ stable in plasma at 5 min p.i. While a minor hydrophilic metabolite peak was observed, its identity was not interrogated in this study. The stability of the compound is promising for translation or for repositioning as a radiotherapeutic agent. The 1,4,7,10-tetraazacyclododecane-1,4,7,10tetraacetic acid (DOTA) chelator can form stable complexes with therapeutic trivalent radiometals such as ${ }^{90} \mathrm{Y}$-yttrium or ${ }^{177} \mathrm{Lu}$-lutetium, to create a theranostic pair.

Dosimetry was calculated for mice and extrapolated to the adult human male. When compared with $\left[{ }^{68} \mathrm{Ga}\right] \mathrm{Ga}$-NeoBOMB1, the absorbed dose for $\left.{ }^{68} \mathrm{Ga}\right] \mathrm{Ga}$-ProBOMB1 in mice was lower across all organs except for urinary bladder (9.33 vs $10.00 \mathrm{mGy} / \mathrm{MBq})$. With $\left[{ }^{68} \mathrm{Ga}\right] \mathrm{Ga}-\mathrm{ProBOMB} 1$, mice received approximately one-sixth and one-tenth the estimated absorbed 
dose for kidneys and pancreas. For the human model, lower doses were also obtained for $\left[{ }^{68} \mathrm{Ga}\right] \mathrm{Ga}-P r o B O M B 1$. Accordingly, the average adult male is predicted to receive approximately one-quarter and one-twentieth the absorbed dose for kidneys and pancreas, respectively.

\section{CONCLUSION}

We synthesized a novel GRPR imaging agent, $\left[{ }^{68} \mathrm{Ga}\right] \mathrm{Ga}-$ ProBOMB1, based on the $\left[\mathrm{Leu}^{13} \psi \mathrm{AA}^{14}\right] \mathrm{BBN}$ family. The radiopharmaceutical exhibited nanomolar affinity for GRPR and high stability in vivo. $\left[{ }^{68} \mathrm{Ga}\right] \mathrm{Ga}$-ProBOMB1 was able to generate high-contrast $\mathrm{PET}$ images with good tumor uptake in a prostate cancer model. $\left[{ }^{68} \mathrm{Ga}\right] \mathrm{Ga}$-ProBOMB1 had a better dosimetry profile compared with $\left[{ }^{68} \mathrm{Ga}\right] \mathrm{Ga}-\mathrm{NeoBOMB} 1$ and warrants further translational studies.

\section{MATERIALS AND METHODS}

General Methods. All reagents and solvents were purchased from commercial sources and used without further purification. $\left[\mathrm{D}-\mathrm{Phe}^{6}{ }^{6}\right.$,Leu-NHEt ${ }^{13}$, des-Met $\left.{ }^{14}\right]$ bombesin(6-14) and bombesin were purchased from Bachem and AnaSpec, respectively. Other peptides were synthesized on an AAPPTec Endeavor 90 peptide synthesizer. HPLC was performed on an Agilent 1260 infinity system (model 1200 quaternary pump, model 1200 UV absorbance detector set at $220 \mathrm{~nm}$, Bioscan NaI scintillation detector). HPLC columns used were a semipreparative column (Luna $\mathrm{C} 18,5 \mu \mathrm{m}, 250 \times 10 \mathrm{~mm}$ ) and an analytical column (Luna, C18, $5 \mu, 250 \times 4.6 \mathrm{~mm}$ ) from Phenomenex. Mass analyses were performed using an AB SCIEX 4000 QTRAP mass spectrometer with an electrospray ionization (ESI) ion source. ${ }^{68} \mathrm{Ga}$ - gallium was eluted from an iThemba Labs generator and purified according to previously published procedures using a DGA resin column from Eichrom Technologies LLC. ${ }^{34}$ Radioactivity of ${ }^{68} \mathrm{Ga}$-labeled peptides was measured using a Capintec CRC-25R/W dose calibrator, and the radioactivity in tissues collected from biodistribution studies were counted using a PerkinElmer Wizard 2480 gamma counter.

Synthesis of Fmoc-p-aminomethylaniline. FmocOSu $(10.12 \mathrm{~g}, 30 \mathrm{mmol})$ in $60 \mathrm{~mL}$ acetonitrile was added dropwise to a solution of 4-aminobenzylamine $(3.67 \mathrm{~g}, 30 \mathrm{mmol})$ and triethylamine $(2.79 \mathrm{~mL}, 30 \mathrm{mmol})$ in $30 \mathrm{~mL}$ acetonitrile and stirred overnight. Water $(100 \mathrm{~mL})$ was added to the reaction mixture and the precipitate was collected after filtration. The precipitate was washed thrice with ethanol/ether $(1: 1,50 \mathrm{~mL})$ and dried under vacuum to obtain the product as white powder (yield: $5.5 \mathrm{~g}, 53 \%) .{ }^{1} \mathrm{H}$ NMR $\left(300 \mathrm{MHz}, \mathrm{DMSO}-d_{6}\right): \delta 7.89(\mathrm{~d}, J$ $=7.4 \mathrm{~Hz}, 2 \mathrm{H}, A r), 7.70(\mathrm{~d}, J=7.4 \mathrm{~Hz}, 2 \mathrm{H}, A r), 7.42(\mathrm{t}, J=7.4 \mathrm{~Hz}$, $2 \mathrm{H}, A r), 7.32(\mathrm{t}, J=7.5 \mathrm{~Hz}, 2 \mathrm{H}, A r), 6.89(\mathrm{~d}, J=8.2 \mathrm{~Hz}, 2 \mathrm{H}, A r)$, $6.50(\mathrm{~d}, J=8.2 \mathrm{~Hz}, 2 \mathrm{H}, A r), 4.94\left(\mathrm{~s}, 2 \mathrm{H}, \mathrm{NH}_{2}\right), 4.31$ (d, $J=6.9$ $\left.\mathrm{Hz}, 2 \mathrm{H}, \mathrm{OCH}_{2}\right), 4.21\left(\mathrm{t}, J=6.8 \mathrm{~Hz}, 1 \mathrm{H}, \mathrm{CH}_{2} \mathrm{CH}\right), 4.00(\mathrm{~d}, J=$ $\left.6.0 \mathrm{~Hz}, 2 \mathrm{H}, \mathrm{NHCH}_{2}\right)$. ESI-MS: calculated $[\mathrm{M}+\mathrm{H}]^{+}$for Fmocp-aminomethylaniline $\mathrm{C}_{22} \mathrm{H}_{20} \mathrm{~N}_{2} \mathrm{O}_{2}$, 345.2; found, 345.2.

Synthesis of Fmoc- $p$-aminomethylaniline Diglycolate. Diglycolic anhydride $(1.09 \mathrm{~g}, 9.4 \mathrm{mmol})$ was added to a suspension of Fmoc-p-aminomethylaniline (2.94 g, $8.6 \mathrm{mmol}$ ) in dichloromethane $(30 \mathrm{~mL})$. The reaction mixture was stirred for $2 \mathrm{~h}$ and filtered. The collected solid was washed thrice with dichloromethane $(50 \mathrm{~mL})$ and dried under vacuum to obtain the product as white powder (yield: $2.87 \mathrm{~g}, 73 \%) .{ }^{1} \mathrm{H}$ NMR (300 $\left.\mathrm{MHz}, \mathrm{DMSO}-d_{6}\right): \delta 9.87(\mathrm{~s}, 1 \mathrm{H}, \mathrm{NH}), 7.89(\mathrm{~d}, J=7.4 \mathrm{~Hz}, 2 \mathrm{H}$, $A r), 7.80\left(\mathrm{t}, J=6.0 \mathrm{~Hz}, 1 \mathrm{H}, \mathrm{NHCH}_{2}\right), 7.69$ (d, $J=7.4 \mathrm{~Hz}, 2 \mathrm{H}$,
$A r), 7.57(\mathrm{~d}, J=8.4 \mathrm{~Hz}, 2 \mathrm{H}, A r), 7.42(\mathrm{t}, J=7.3 \mathrm{~Hz}, 2 \mathrm{H}, A r), 7.32$ $(\mathrm{t}, J=7.3 \mathrm{~Hz}, 2 \mathrm{H}, A r), 7.15(\mathrm{~d}, J=8.4 \mathrm{~Hz}, 2 \mathrm{H}, A r), 4.35$ (d, $J=$ $\left.6.8 \mathrm{~Hz}, 2 \mathrm{H}, \mathrm{OCH}_{2}\right), 4.27-4.22\left(\mathrm{~m}, 1 \mathrm{H}, \mathrm{CH}_{2} \mathrm{CH}\right), 4.22-4.19$ $\left(\mathrm{m}, 2 \mathrm{H}, \mathrm{NHCH}_{2}\right), 4.18-4.08\left(\mathrm{~m}, 4 \mathrm{H}, \mathrm{O}\left(\mathrm{CH}_{2}\right)_{2}\right)$. ESI-MS: calculated $[\mathrm{M}+\mathrm{H}]^{+}$for Fmoc-p-aminomethylaniline diglycolate $\mathrm{C}_{26} \mathrm{H}_{24} \mathrm{~N}_{2} \mathrm{O}_{6}, 461.2$; found, 461.3.

Synthesis of ProBOMB1. ProBOMB1 was synthesized on solid-phase using Fmoc-based approach. Rink amide-MBHA resin $(0.3 \mathrm{mmol})$ was treated with $20 \%$ piperidine in $N, N$ dimethylformamide (DMF) to remove Fmoc protecting group. Fmoc-Pro-OH pre-activated with HATU (3 equiv), HOAt (3 equiv), and $N, N$-diisopropylethylamine (DIEA, 6 equiv) was coupled to the resin. After removal of Fmoc protecting group, Fmoc-Leu-aldehyde synthesized per published procedures (10 equiv), was coupled to the resin by reductive amination in the presence of excess sodium cyanoborohydride (33 equiv) in $5 \mathrm{~mL}$ DMF (1\% acetic acid). Fmoc-His(Trt)-OH, Fmoc-Gly-OH, Fmoc-Val-OH, Fmoc-Ala-OH, Fmoc-Trp(Boc)-OH, Fmoc$\mathrm{G} \ln (\mathrm{Trt})-\mathrm{OH}$, Fmoc-D-Phe-OH [pre-activated with HATU (3 equiv), HOAt ( 3 equiv) and DIEA ( 6 equiv)], Fmoc-protected pABzA-DIG linker [pre-activated with HATU (3 equiv) and DIEA (6 equiv)], and DOTA [pre-activated with HATU (3 equiv) and DIEA (6 equiv)] were coupled to the resin sequentially. The peptide was deprotected and cleaved from the resin with a cleaving cocktail of trifluoroacetic acid (TFA) $81.5 \%$, triisopropylsilane $1 \%$, water $5 \%$, 1,2-ethanedithiol (EDT) $2.5 \%$, thioanisole $5 \%$, and phenol $5 \%$ for $4 \mathrm{~h}$ at room temperature. After filtration, the peptide was precipitated by addition of cold diethyl ether, collected by centrifugation, and purified by HPLC (semi-preparative column; 23\% acetonitrile and $0.1 \%$ TFA in water, flow rate: $4.5 \mathrm{~mL} / \mathrm{min}$ ). The isolated yield was $1.1 \%$. Retention time: $11.0 \mathrm{~min}$. ESI-MS: calculated $[\mathrm{M}+\mathrm{H}]^{+}$for ProBOMB1 $\mathrm{C}_{79} \mathrm{H}_{113} \mathrm{~N}_{20} \mathrm{O}_{19}, 1645.8$; found, 1645.8 .

Synthesis of NeoBOMB1. NeoBOMB1 was synthesized on solid-phase using Fmoc-based approach. BAL resin (1\% DVB, $0.3 \mathrm{mmol}$ ) was swelled in DMF, drained, and activated by shaking for $10 \mathrm{~min}$ in $4 \mathrm{~mL}$ of 47.5:47.5:5 methanol/DMF/ acetic acid solution. 2,6-Dimethylheptane-4-amine (10 equiv) in $2 \mathrm{~mL}$ of 1:1 methanol/DMF solution was added and the mixture was shaken for $1 \mathrm{~h}$. Sodium cyanoborohydride (10 equiv) was added, and the mixture was shaken for $16 \mathrm{~h}$. The reaction vial was drained and washed with dichloromethane and DMF. Fmoc-His(Trt)-OH (3 equiv) preactivated with HATU (3 equiv), HOAt ( 3 equiv) and DIEA ( 8 equiv) in DMF $(6 \mathrm{~mL})$ was then added to the reaction vial and shaken for at least $1 \mathrm{~h}$. Fmoc-deprotection was performed using $20 \%$ piperidine in DMF. Using a similar procedure, Fmoc-Gly-OH (HATU and HOAt substituted by HBTU and HOBt), Fmoc-Val-OH, FmocAla-OH, Fmoc-Trp(Boc)-OH, Fmoc-Gln(Trt)-OH, Fmoc-DPhe-OH, Fmoc-protected pABzA-DIG linker, and DOTA were subsequently coupled to the peptide sequence. The peptide was cleaved with a mixture of $82.5 / 5 / 2.5 / 5 / 5$ TFA/water/EDT/ thioanisole/phenol and purified by HPLC (Agilent 1260 Infinity II Preparative System) using the preparative column (Gemini 5 $\mu \mathrm{m}$ NX-C18 $110 \AA$ Å, LC column $50 \times 30 \mathrm{~mm} ; 29-30.5 \%$ acetonitrile and $0.1 \%$ TFA in water in 10 minutes and held at $30.5 \%$ acetonitrile and $0.1 \%$ TFA afterward; flow rate: $30 \mathrm{~mL} /$ $\mathrm{min})$. The isolated yield was $39 \%$. Retention time: $9.0 \mathrm{~min}$. ESIMS: calculated $[\mathrm{M}+\mathrm{H}]^{+}$for NeoBOMB1 $\mathrm{C}_{77} \mathrm{H}_{111} \mathrm{~N}_{18} \mathrm{O}_{18}$, 1575.8; found, 1576.0.

Synthesis of Nonradioactive Standards. A solution of ProBOMB1 (1.3 mg, $0.79 \mu \mathrm{mol})$ and $\mathrm{GaCl}_{3}(0.284 \mathrm{M}, 13.9 \mu \mathrm{L}$, 
$3.90 \mu \mathrm{mol})$ in $500 \mu \mathrm{L}$ sodium acetate buffer $(0.1 \mathrm{M}, \mathrm{pH} 4.2)$ was incubated at $80{ }^{\circ} \mathrm{C}$ for $15 \mathrm{~min}$ and purified by HPLC using the semipreparative column (23\% acetonitrile and $0.1 \%$ TFA in water; flow rate: $4.5 \mathrm{~mL} / \mathrm{min}$ ). The isolated yield was $67 \%$. Retention time: $15.7 \mathrm{~min}$. ESI-MS: calculated $[\mathrm{M}+\mathrm{H}]^{+}$for GaProBOMB1 $\mathrm{C}_{79} \mathrm{H}_{110} \mathrm{~N}_{20} \mathrm{O}_{19} \mathrm{Ga}$, 1711.8; found, 1711.7. A solution of NeoBOMB1 $(2.0 \mathrm{mg}, 1.17 \mu \mathrm{mol})$ and $\mathrm{GaCl}_{3}$ $(0.265 \mathrm{M}, 47 \mu \mathrm{L}, 12.46 \mu \mathrm{mol})$ in $460 \mu \mathrm{L}$ sodium acetate buffer $(0.1 \mathrm{M}, \mathrm{pH} 4.2)$ and $60 \mu \mathrm{L}$ acetonitrile was incubated at $80^{\circ} \mathrm{C}$ for $15 \mathrm{~min}$ and purified by HPLC using the preparative column $30 \%$ acetonitrile and $0.1 \%$ TFA in water; flow rate: $30 \mathrm{~mL} / \mathrm{min}$. The isolated yield was $38 \%$. Retention time: $13.0 \mathrm{~min}$. ESI-MS: calculated $[\mathrm{M}+\mathrm{H}]^{+}$for Ga-NeoBOMB1 $\mathrm{C}_{77} \mathrm{H}_{109} \mathrm{~N}_{18} \mathrm{O}_{18} \mathrm{Ga}$, 1643.7; found, 1644.0.

Radiolabeling. Purified ${ }^{68} \mathrm{GaCl}_{3}(289-589 \mathrm{MBq}$, in $0.6 \mathrm{~mL}$ water) was added to $0.6 \mathrm{~mL}$ of HEPES buffer ( $2 \mathrm{M}, \mathrm{pH} 5.3$ ) containing ProBOMB1 or NeoBOMB1 $(25 \mu \mathrm{g})$. The mixture was heated by a microwave oven (Danby DMW7700WDB; power setting 2; $1 \mathrm{~min}$ ). HPLC purification was used to separate ${ }^{68} \mathrm{Ga}$-labeled product from the unlabeled precursor (semipreparative column; $23 \%$ acetonitrile and $0.1 \%$ TFA in water for ProBOMB $1 ; 35 \%$ acetonitrile and $0.1 \% \mathrm{HCOOH}$ in water for NeoBOMB1; flow rate: $4.5 \mathrm{~mL} / \mathrm{min}$ ). Retention times: 23.7 $\min \left(\left[{ }^{68} \mathrm{Ga}\right] \mathrm{Ga}-\mathrm{ProBOMB} 1\right) ; 11.0 \mathrm{~min}\left(\left[{ }^{68} \mathrm{Ga}\right] \mathrm{Ga}-\mathrm{Neo}-\right.$ BOMB1). The fraction containing $\left[{ }^{68} \mathrm{Ga}\right] \mathrm{Ga}-\mathrm{ProBOMB} 1$ or $\left[{ }^{68} \mathrm{Ga}\right] \mathrm{Ga}-\mathrm{NeoBOMB} 1$ was collected, diluted with water (50 $\mathrm{mL})$, and passed through a C18 Sep-Pak cartridge. The $\left[{ }^{68} \mathrm{Ga}\right] \mathrm{Ga}$-ProBOMB1 or $\left[{ }^{68} \mathrm{Ga}\right] \mathrm{Ga}-\mathrm{NeoBOMB} 1$ trapped on the cartridge was eluted off with ethanol $(0.4 \mathrm{~mL})$ and diluted with phosphate-buffered saline (PBS). Quality control was performed using the analytical column: $24 \%$ acetonitrile and $0.1 \%$ TFA in water $\left(\left[{ }^{68} \mathrm{Ga}\right] \mathrm{Ga}-\right.$ ProBOMB 1$) ; 35 \%$ acetonitrile and $0.1 \%$ TFA in water $\left(\left[{ }^{68} \mathrm{Ga}\right] \mathrm{Ga}-\mathrm{NeoBOMB} 1\right)$; flow rate: 2 $\mathrm{mL} / \mathrm{min}$. Retention times: $7.9 \mathrm{~min}\left(\left[{ }^{68} \mathrm{Ga}\right] \mathrm{Ga}-\right.$ ProBOMB1 $) ; 9.4$ $\min \left(\left[{ }^{68} \mathrm{Ga}\right] \mathrm{Ga}-\mathrm{NeoBOMB} 1\right)$.

$\log D_{7.4}$ Measurements. $\log D_{7.4}$ values of radiolabeled peptides were measured using the shake flask method as previously reported. ${ }^{34}$

Cell Culture. The PC-3 prostate adenocarcinoma cell line (ATCC-CRL-1435) was cultured in a humidified incubator (5\% $\mathrm{CO}_{2} ; 37^{\circ} \mathrm{C}$ ) in F-12K medium (Life Technologies Corporations) supplemented with $20 \%$ fetal bovine serum (SigmaAldrich), 100 I.U./mL penicillin, and $100 \mu \mathrm{g} / \mathrm{mL}$ streptomycin (Life Technologies).

Competition Binding Assay. The in vitro competition binding assay was modified from previously published procedures. $^{35}$ PC- 3 cells were seeded at $2 \times 10^{5}$ cells/well in 24 well poly-D-lysine plates $18-24 \mathrm{~h}$ prior to the experiment. The growth medium was replaced by $400 \mu \mathrm{L}$ of reaction medium. Cells were incubated for $30-60 \mathrm{~min}$ at $37{ }^{\circ} \mathrm{C}$. Nonradioactive peptides in $50 \mu \mathrm{L}$ of decreasing concentrations $(10 \mu \mathrm{M}$ to $1 \mathrm{pM})$ and $50 \mu \mathrm{L}$ of $0.011 \mathrm{nM}\left[{ }^{125} \mathrm{I}^{-T_{y r}}{ }^{4}\right]$ bombesin were added to wells. The cells were incubated with moderate agitation for $1 \mathrm{~h}$ at $27^{\circ} \mathrm{C}$, washed thrice with ice-cold PBS, harvested by trypsinization, and measured for activity on the gamma counter. Data were analyzed using nonlinear regression (one binding site model for competition assay) with GraphPad Prism 7.

Fluorometric Calcium Release Assay. Calcium release assays were performed using a FLIPR Calcium 6 assay kit (Molecular Devices) according to published procedures. ${ }^{36}$ Briefly, $5 \times 10^{4}$ PC-3 cells were seeded overnight in 96-well clear bottom black plates. The growth medium was replaced with loading buffer containing a calcium-sensitive dye and incubated for $30 \mathrm{~min}$ at $37{ }^{\circ} \mathrm{C}$. The plate was placed in a FlexStation 3 microplate reader (Molecular Devices) and baseline fluorescent signals were acquired for $15 \mathrm{~s}$. Five or 50 $\mathrm{nM}$ of Ga-ProBOMB1, [D-Phe ${ }^{6}$, Leu-NHEt ${ }^{13}$, des-Met ${ }^{14}$ ]bombesin(6-14), bombesin, ATP (positive control), or PBS (negative control) was added to the cells, and the fluorescent signals were acquired for $105 \mathrm{~s}$. The relative fluorescence unit (RFU $=\max -\min$ ) was used to determine the agonistic/ antagonistic properties.

Animal Model. Animal experiments were approved by the Animal Ethics Committee of the University of British Columbia. Male NOD.Cg-Rag1 ${ }^{\text {tm1Mom }}$ Il2 $\mathrm{rg}^{\text {tm1Wjl }} /$ SzJ (NRG) mice obtained from an in-house colony were subcutaneously inoculated with $5 \times 10^{6} \mathrm{PC}-3$ cells $(100 \mu \mathrm{L} ; 1: 1 \mathrm{PBS} /$ Matrigel $)$, and tumors were grown for 2-3 weeks.

PET/CT Imaging. PC-3 tumor-bearing mice were sedated $\left(2.5 \%\right.$ isoflurane in $\left.\mathrm{O}_{2}\right)$ for i.v. injection of radiotracer $(4.67 \pm$ $0.91 \mathrm{MBq})$ with or without $100 \mu \mathrm{g}$ of $\left[\mathrm{D}-\mathrm{Phe}^{6}{ }^{6}\right.$ Leu-NHEt ${ }^{13}$, des$\left.\mathrm{Met}^{14}\right]$ bombesin(6-14). Mice were sedated and scanned (Siemens Inveon microPET/CT) with body temperature maintained by heating pad. The CT scan was obtained ( 80 $\mathrm{kV}$; $500 \mu \mathrm{A}$; 3 bed positions; $34 \%$ overlap; $220^{\circ}$ continuous rotation) followed by a $10 \mathrm{~min}$ static PET at 1 or $2 \mathrm{~h}$ p.i. of the radiotracer. PET data were acquired in list mode, reconstructed using three-dimensional ordered-subsets expectation maximization ( 2 iterations) followed by a fast maximum a priori algorithm (18 iterations) with CT-based attenuation correction. Images were analyzed using the Inveon Research Workplace software (Siemens Healthineers).

Biodistribution. PC-3 tumor-bearing mice were anesthetized $\left(2.5 \%\right.$ isoflurane in $\left.\mathrm{O}_{2}\right)$ for i.v. injection of radiotracer $(1.84 \pm 0.99 \mathrm{MBq})$ with or without $100 \mu \mathrm{g}$ of $\left[\mathrm{D}-\mathrm{Phe}^{6}\right.$,Leu$\mathrm{NHEt}^{13}$, des-Met $\left.{ }^{14}\right]$ bombesin(6-14). The mice were sacrificed by $\mathrm{CO}_{2}$ inhalation at $30 \mathrm{~min}, 1 \mathrm{~h}$, and $2 \mathrm{~h}$ p.i. Blood was collected by cardiac puncture. Organs/tissues were harvested, rinsed with PBS, blotted dry, and weighed. The activity in tissues was assayed by gamma counter and expressed as the percentage injected dose per gram of tissue (\% ID/g).

In Vivo Stability. $\left[{ }^{68} \mathrm{Ga}\right]$ Ga-ProBOMB1 $(16.1 \pm 2.9 \mathrm{MBq})$ was intravenously injected into two male NRG mice. After a 5 min uptake period, mice were sedated/euthanized, and blood was collected. The plasma was isolated and analyzed with radioHPLC (24\% acetonitrile and 0.1\% TFA in water; flow rate: 2.0 $\mathrm{mL} / \mathrm{min}$ ) following published procedures. ${ }^{36}$ Retention time of $\left[{ }^{68} \mathrm{Ga}\right]$ Ga-ProBOMB1: 8.8 min.

Dosimetry. Biodistribution data (\% ID/g) were decayed to the appropriate time-point and fitted to monoexponential or biexponential models using a Python script developed in-house (Python Software Foundation, v3.5). The choice of fit was based on $R^{2}$ and residuals. The resulting time-activity curve was integrated to obtain the residence time which, multiplied by the model organ mass (25 g MOBY mouse phantom), provided OLINDA (Hermes Medical Solution, v2.0) with input values to calculate dosimetry. ${ }^{37,38}$

Statistical Analysis. The binding affinity was analyzed with one-way ANOVA with a post hoc $t$-test on GraphPad Prism 7. Statistics for biodistribution data were computed using R ( R Foundation for Statistical Computing, v.3.4.2). Outliers were identified with one round of Grubbs' test (threshold: $p<0.01$ ). The Shapiro-Wilk test was used to determine if distributions were normal (threshold: $p>0.05$ ); if they were, Welch's $t$-test 
was used, or Wilcoxon's test otherwise. Multiple comparisons were corrected by Holm's method.

\section{ASSOCIATED CONTENT}

\section{S Supporting Information}

The Supporting Information is available free of charge on the ACS Publications website at DOI: 10.1021/acsomega.8b03293.

Additional data of receptor binding assays, calcium release assays, biodistribution studies, and radiation dosimetry calculations(PDF)

\section{AUTHOR INFORMATION}

\section{Corresponding Authors}

*E-mail: klin@bccrc.ca. Phone: (604)-675-8208. Fax: (604)675-8218 (K.-S.L.).

*E-mail: fbenard@bccrc.ca. Phone: (604)-675-8206. Fax: (604)-675-8218 (F.B.).

\section{ORCID}

Chengcheng Zhang: 0000-0001-5786-4748

Kuo-Shyan Lin: 0000-0002-0739-0780

\section{Author Contributions}

IJ.L. and E.R.contributed equally to this work.

\section{Funding}

The Canadian Institutes of Health Research (FDN-148465) and the BC Leading Edge Endowment Fund.

\section{Notes}

The authors declare no competing financial interest.

\section{ACKNOWLEDGMENTS}

This work was supported by the Canadian Institutes of Health Research (FDN-148465) and the BC Leading Edge Endowment Fund. The authors thank Jinhe Pan, Navjit Hundal-Jabal, Nadine Colpo, and Helen Merkens for technical assistance.

\section{REFERENCES}

(1) Roesler, R.; Schwartsmann, G. Gastrin-Releasing Peptide Receptors in the Central Nervous System: Role in Brain Function and as a Drug Target. Frontiers in Endocrinology. Frontiers Media SA, 2012; p 159.

(2) Bitar, K. N.; Zhu, X.-X. Expression of Bombesin-Receptor Subtypes and Their Differential Regulation of Colonic Smooth Muscle Contraction. Gastroenterology 1993, 105, 1672-1680.

(3) Weber, H. C. Regulation and Signaling of Human Bombesin Receptors and Their Biological Effects. Curr. Opin. Endocrinol. Diabetes Obes. 2009, 16, 66-71.

(4) Jensen, R. T.; Battey, J. F.; Spindel, E. R.; Benya, R. V. International Union of Pharmacology. LXVIII. Mammalian Bombesin Receptors: Nomenclature, Distribution, Pharmacology, Signaling, and Functions in Normal and Disease States. Pharmacol. Rev. 2008, 60, 142.

(5) Cornelio, D.; Roesler, R.; Schwartsmann, G. Gastrin-Releasing Peptide Receptor as a Molecular Target in Experimental Anticancer Therapy. Ann. Oncol. 2007, 18, 1457-1466.

(6) Maina, T.; Nock, B. A.; Kulkarni, H.; Singh, A.; Baum, R. P. Theranostic Prospects of Gastrin-Releasing Peptide Receptor-Radioantagonists in Oncology. Pet. Clin. 2017, 12, 297-309.

(7) Lin, K. S.; Luu, A.; Baidoo, K. E.; Hashemzadeh-Gargari, H.; Chen, M. K.; Pili, R.; Pomper, M.; Carducci, M.; Wagner, H. N. A New High Affinity Technetium Analogue of Bombesin Containing DTPA as a Pharmacokinetic Modifier. Bioconjugate Chemistry; American Chemical Society, 2004; Vol. 15, pp 1416-1423.

(8) Inkster, J.; Lin, K.-S.; Ait-Mohand, S.; Gosselin, S.; Bénard, F.; Guérin, B.; Pourghiasian, M.; Ruth, T.; Schaffer, P.; Storr, T. 2-
Fluoropyridine prosthetic compounds for the $18 \mathrm{~F}$ labeling of bombesin analogues. Bioorg. Med. Chem. Lett 2013, 23, 3920-3926.

(9) Mansi, R.; Minamimoto, R.; Macke, H.; Iagaru, A. H. BombesinTargeted PET of Prostate Cancer. J. Nucl. Med. 2016, 57, 67S-72S.

(10) Bodei, L.; Ferrari, M.; Nunn, A.; Llull, J.; Cremonesi, M.; Martano, L.; Laurora, G.; Scardino, E.; Tiberini, S.; Bufi, G.; et al. 177Lu-AMBA Bombesin Analogue in Hormone Refractory Prostate Cancer Patients: A Phase I Escalation Study with Single-Cycle Administrations. JOINT EANM-EORTC Symposium; 2007.

(11) Sah, B.-R.; Burger, I. A.; Schibli, R.; Friebe, M.; Dinkelborg, L.; Graham, K.; Borkowski, S.; Bacher-Stier, C.; Valencia, R.; Srinivasan, A.; et al. Dosimetry and First Clinical Evaluation of the New 18FRadiolabeled Bombesin Analogue BAY 864367 in Patients with Prostate Cancer. J. Nucl. Med. 2015, 56, 372-378.

(12) Zang, J.; Mao, F.; Wang, H.; Zhang, J.; Liu, Q.; Peng, L.; Li, F.; Lang, L.; Chen, X.; Zhu, Z. 68Ga-NOTA-RM26 PET/CT in the Evaluation of Breast Cancer. Clin. Nucl. Med. 2018, 43, 663-669.

(13) Nock, B. A.; Kaloudi, A.; Lymperis, E.; Giarika, A.; Kulkarni, H. R.; Klette, I.; Singh, A.; Krenning, E. P.; de Jong, M.; Maina, T.; et al. Theranostic Perspectives in Prostate Cancer with the Gastrin-Releasing Peptide Receptor Antagonist NeoBOMB1: Preclinical and First Clinical Results. J. Nucl. Med. 2016, 58, 75-80.

(14) Maina, T.; Bergsma, H.; Kulkarni, H. R.; Mueller, D.; Charalambidis, D.; Krenning, E. P.; Nock, B. A.; de Jong, M.; Baum, R. P. Preclinical and First Clinical Experience with the GastrinReleasing Peptide Receptor-Antagonist [68Ga]SB3 and PET/CT. Eur. J. Nucl. Med. Mol. Imaging 2015, 43, 964-973.

(15) Kahkonen, E.; Jambor, I.; Kemppainen, J.; Lehtio, K.; Gronroos, T. J.; Kuisma, A.; Luoto, P.; Sipila, H. J.; Tolvanen, T.; Alanen, K.; et al. In Vivo Imaging of Prostate Cancer Using [68Ga]-Labeled Bombesin Analog BAY86-7548. Clin. Cancer Res. 2013, 19, 5434-5443.

(16) Wieser, G.; Mansi, R.; Grosu, A. L.; Schultze-Seemann, W.; Dumont-Walter, R. A.; Meyer, P. T.; Maecke, H. R.; Reubi, J. C.; Weber, W. A. Positron Emission Tomography (PET) Imaging of Prostate Cancer with a Gastrin Releasing Peptide Receptor Antagonist from Mice to Men. Theranostics 2014, 4, 412-419.

(17) Coy, DH; Heinz-Erian, P.; Jiang, NY; Sasaki, Y.; Taylor, J.; Moreau, JP; Wolfrey, WT; Gardner, JD; Jensen, RT Probing peptide backbone function in bombesin. A reduced peptide bond analogue with potent and specific receptor antagonist activity. J Biol Chem 1988, 263, 5056-5060.

(18) Reile, H.; Cai, R. Z.; Armatis, P.; Schally, A. V. New Antagonists of Bombesin/Gastrin-Releasing Peptide with C-Terminal Leu (CH2N)Tac-NH2. Int. J. Oncol. 1995, 7, 749-754.

(19) Bajo, A. M.; Schally, A. V.; Krupa, M.; Hebert, F.; Groot, K.; Szepeshazi, K. Bombesin antagonists inhibit growth of MDA-MB-435 estrogen-independent breast cancers and decrease the expression of the ErbB-2/HER-2 oncoprotein and c-junand c-fosoncogenes. Proc. Natl. Acad. Sci. U.S.A. 2002, 99, 3836-3841.

(20) Koppán, M.; Halmos, G.; Arencibia, J. M.; Lamharzi, N.; Schally, A. V. Bombesin/Gastrin-Releasing Peptide Antagonists RC-3095 and RC-3940-II Inhibit Tumor Growth and Decrease the Levels and MRNA Expression of Epidermal Growth Factor Receptors in H-69 Small Cell Lung Carcinoma. Cancer 1998, 83, 1335-1343.

(21) Shirahige, Y.; Cai, R.-Z.; Szepeshazi, K.; Halmos, G.; Pinski, J.; Groot, K.; Schally, A. V. Inhibitory Effect of Bombesin/GastrinReleasing Peptide (GRP) Antagonists RC-3950-II and RC-3095 on MCF-7 MIII Human Breast Cancer Xenografts in Nude Mice. Biomed. Pharmacother. 1994, 48, 465-472.

(22) Cai, R. Z.; Qin, Y.; Ertl, T.; Schally, A. V. New Pseudononapeptide Bombesin Antagonists with C-Terminal LeuPsi(CH2N)Tac-NH2 Show High Binding Affinity to Bombesin/GRP Receptors on CFPAC-1 Human Pancreatic Cancer Cells. Int. J. Oncol. 1995, 6, 1165-1172.

(23) Jungwirth, A.; Pinski, J.; Galvan, G.; Halmos, G.; Szepeshazi, K.; Gai, R. Z.; Groot, K.; Vadillo-buenfil, M.; Schally, A. V. Inhibition of Growth of Androgen-Independent DU-145 Prostate Cancer in Vivo by Luteinising Hormone-Releasing Hormone Antagonist Cetrorelix and 
Bombesin Antagonists RC-3940-II and RC-3950-II. Eur. J. Cancer, Part A 1997, 33, 1141-1148.

(24) Morgat, C.; MacGrogan, G.; Brouste, V.; Vélasco, V.; Sévenet, N.; Bonnefoi, H.; Fernandez, P.; Debled, M.; Hindié, E. Expression of Gastrin-Releasing Peptide Receptor in Breast Cancer and Its Association with Pathologic, Biologic, and Clinical Parameters: A Study of 1,432 Primary Tumors. J. Nucl. Med. 2017, 58, 1401-1407.

(25) Stoykow, C.; Erbes, T.; Maecke, H. R.; Bulla, S.; Bartholomä, M.; Mayer, S.; Drendel, V.; Bronsert, P.; Werner, M.; Gitsch, G.; et al. Gastrin-releasing Peptide Receptor Imaging in Breast Cancer Using the Receptor Antagonist 68Ga-RM2 And PET. Theranostics 2016, 6, $1641-1650$

(26) Sonni, I.; Baratto, L.; Iagaru, A. Imaging of Prostate Cancer Using Gallium-68-Labeled Bombesin. PET Clinics; Elsevier, 2017; pp 159171.

(27) Eder, M.; Schäfer, M.; Bauder-Wüst, U.; Haberkorn, U.; Eisenhut, M.; Kopka, K. Preclinical Evaluation of a Bispecific LowMolecular Heterodimer Targeting Both PSMA and GRPR for Improved PET Imaging and Therapy of Prostate Cancer. Prostate 2014, 74, 659-668.

(28) Minamimoto, R.; Hancock, S.; Schneider, B.; Chin, F. T.; Jamali, M.; Loening, A.; Vasanawala, S.; Gambhir, S. S.; Iagaru, A. Pilot Comparison of 68Ga-RM2 PET and 68Ga-PSMA-11 PET in Patients with Biochemically Recurrent Prostate Cancer. J. Nucl. Med. 2015, 57, $557-562$.

(29) Lin, J.-T.; Coy, D. H.; Mantey, S. A.; Jensen, R. T. Comparison of the Peptide Structural Requirements for High Affinity Interaction with Bombesin Receptors. Eur. J. Pharmacol. 1995, 294, 55-69.

(30) Dalm, S. U.; Bakker, I. L.; de Blois, E.; Doeswijk, G. N.; Konijnenberg, M. W.; Orlandi, F.; Barbato, D.; Tedesco, M.; Maina, T.; Nock, B. A.; et al. 68 Ga/ 177 Lu-NeoBOMB1, a Novel Radiolabeled GRPR Antagonist for Theranostic Use in Oncology. J. Nucl. Med. 2016, 58, 293-299.

(31) Fani, M.; Maecke, H. R.; Okarvi, S. M. Radiolabeled Peptides: Valuable Tools for the Detection and Treatment of Cancer. Theranostics 2012, 2, 481-501.

(32) Richter, S.; Wuest, M.; Bergman, C. N.; Krieger, S.; Rogers, B. E.; Wuest, F. Metabolically Stabilized 68Ga-NOTA-Bombesin for PET Imaging of Prostate Cancer and Influence of Protease Inhibitor Phosphoramidon. Mol. Pharm. 2016, 13, 1347-1357.

(33) Nock, B. A.; Maina, T.; Krenning, E. P.; de Jong, M. “To Serve and Protect": Enzyme Inhibitors as Radiopeptide Escorts Promote Tumor Targeting. J. Nucl. Med. 2013, 55, 121-127.

(34) Lin, K.-S.; Pan, J.; Amouroux, G.; Turashvili, G.; Mesak, F.; Hundal-Jabal, N.; Pourghiasian, M.; Lau, J.; Jenni, S.; Aparicio, S.; et al. In Vivo Radioimaging of Bradykinin Receptor B1, a Widely Overexpressed Molecule in Human Cancer. Cancer Res. 2014, 75, 387-393.

(35) Pourghiasian, M.; Liu, Z.; Pan, J.; Zhang, Z.; Colpo, N.; Lin, K.S.; Perrin, D. M.; Bénard, F. 18F-AmBF3-MJ9: A Novel Radiofluorinated Bombesin Derivative for Prostate Cancer Imaging. Bioorg. Med. Chem. 2015, 23, 1500-1506.

(36) Amouroux, G.; Pan, J.; Jenni, S.; Zhang, C.; Zhang, Z.; HundalJabal, N.; Colpo, N.; Liu, Z.; Bénard, F.; Lin, K.-S. Imaging Bradykinin B1 Receptor with 68Ga-Labeled [Des-Arg10]Kallidin Derivatives: Effect of the Linker on Biodistribution and Tumor Uptake. Mol. Pharm. 2015, 12, 2879-2888.

(37) Stabin, M. G.; Sparks, R. B.; Crowe, E. OLINDA/EXM: The Second-Generation Personal Computer Software for Internal Dose Assessment in Nuclear Medicine. J. Nucl. Med. 2005, 46, 1023-1027.

(38) Keenan, M. A.; Stabin, M. G.; Segars, W. P.; Fernald, M. J. RADAR Realistic Animal Model Series for Dose Assessment. J. Nucl. Med. 2010, 51, 471-476. 